\title{
Modern Probe-Assisted Methods for the Specific Detection of Bacteria
}

\author{
Arghavan Shabani1,2, Christophe A. Marquette3, Rosemonde Mandeville1, \\ Marcus F. Lawrence ${ }^{2 *}$ \\ ${ }^{1}$ Biophage Pharma, Montreal, Canada \\ ${ }^{2}$ Department of Chemistry and Biochemistry, Concordia University, Montreal, Canada \\ ${ }^{3}$ Laboratoire de Génie Enzymatique et Biomoléculaire, ICBMS UMR5246-Université Lyon 1, Villeurbanne, \\ France \\ Email: ${ }^{*}$ Marcus.Lawrence@concordia.ca
}

Received 20 December 2014; accepted 11 February 2015; published 15 February 2015

Copyright (C) 2015 by authors and Scientific Research Publishing Inc.

This work is licensed under the Creative Commons Attribution International License (CC BY). http://creativecommons.org/licenses/by/4.0/

(c) (i) Open Access

\section{Abstract}

This review intends to present an overview of methods currently under development for the specific and sensitive detection of pathogenic bacteria that exist in a variety of human environments. Bacteria continue to be a major health threat in general, and much effort is being deployed to counteract this problem. In a first instance, current and efficient techniques in use for the detection of bacteria are described. In a second instance, this review serves to compare the more conventional techniques to emerging technologies for the direct (non-labelled) detection of bacteria (referred to as "biosensors"). These approaches are mainly optical, piezoelectric, and electrochemical in nature. They are cost-effective, quite sensitive, and potentially portable for rapid onsite/real-time detection, and rapid prevention. These devices are comprised of specific chemical/ biochemical probes immobilized onto physical transducers. This work also presents comparisons between the efficiencies (assay time and sensitivity) of various techniques being employed.

\section{Keywords}

Bacteria Detection, Probes, Optical, Piezoelectric, and Electrochemical Biosensors

\section{Introduction}

Bacteria are microorganisms that can spread easily and rapidly in a moist environment at favorable temperatures.

${ }^{*}$ Corresponding author.

How to cite this paper: Shabani, A., Marquette, C.A., Mandeville, R. and Lawrence, M.F. (2015) Modern Probe-Assisted Methods for the Specific Detection of Bacteria. J. Biomedical Science and Engineering, 8, 104-121. 
They may affect animals and humans, causing a variety of infectious diseases. Many infectious diseases result from food and water contamination by pathogenic bacteria and they are the major cause of illness and death in many countries. Some types of bacteria are resistant to changes in environmental conditions and the disease they cause may result in a high fatality rate. It should be noted also that some of these pathogenic bacteria are considered to be potential biological warfare agents (see Table 1). E. coli, ever rampant, has become one of the most important organisms to cause disease. E. coli can easily spread and contaminate food such as ground beef, raw milk, chicken, and vegetables. E. coli O157:H7, first discovered in 1982, is the strain that is the most dangerous food-born pathogen. This bacteria strain produces a large amount of potent toxin, causing several types of damage such as hemolytic uremic syndrome and hemorrhagic colitis. Both cases cause watery diarrhea, followed by bloody diarrhea, kidney failure and in some cases death (especially in children) [1]. It has been determined that the E. coli O157:H7 strain is responsible for over 20,000 cases of diarrhea per year in the United States [2]. Salmonella is a Gram-negative bacteria and another food-born pathogen producing infectious diseases such as salmonellosis, typhoid fever, or other problems. Typhoid fever caused by S. typhi leads to 600,000 deaths annually, most cases occurring in South Asia, Africa, and South America [3]. Generally, infectious dosages by pathogenic bacteria such as Salmonella and E. coli are as low as $10 \mathrm{cells} / \mathrm{mL}$ [4], thus effective and sensitive methods for screening these microorganisms are essential.

\section{Conventional Detection Methods}

The widespread incidents of bacterial contamination of our environment, mainly related to our food and water resources, demand the development of effective testing and analysis techniques that specifically target these microorganisms. Effective testing requires methods of analysis that meet a number of challenging criteria such as short detection time and selectivity. In the following section, we consider many approaches for bacteria detection, from conventional methods to biosensor-based techniques.

The conventional approach to microbiological identification of bacteria involves plating and culturing methods, which allow a morphological evaluation of these microorganisms based on their ability to grow in various media. Almost all bacterial species can be detected using culture-based methods. One of the media used for culture purposes is MacConky's agar, which was first used to isolate Enterobacteriaceae from water, food, and urine in 1905 [2]. This is a nutrient medium that contains bile salts, lactose, and an indicator. By replacing lactose in the standard MacConkey's agar with sorbitol, the agar media was used to detect E. coli O157:H7 species by observing the formation colorless colonies. Lowenstein-Jensen (LJ) medium is another one that can be used to grow bacterial colonies. The LJ medium consists of glycerol, asparagine, some salts and egg, and was used to detect Mycobacteria. Blood agar and bismuth sulfate agar can also be used for the detection of Bacillus and Salmonella species, respectively. Although plating and culturing provide reliable results, they are time consuming. Completion of all the steps can take at least a few days, to several weeks, depending on the species isolated. For example, tubercle bacilli produce visible growth in LJ medium in about two weeks, and adding to this the time for clinical isolation, the process can extend to eight weeks [2].

General instrumental methods for bacteria detection include: microscopic methods, luminescence methods, flow cytometry, infra-red (IR) spectroscopy and mass spectrometry (MS). Among these methods, some have received less attention due to their limitations. For example, Rossi and Warner have reported on the identification of bacteria using IR spectroscopy in 1985 [6]. Using this approach, bacteria were introduced into the IR measurement cell and corresponding IR absorbance spectra were obtained. The main limitation of this technique is that the measurements of the chemical composition of the bacteria usually show similar (indistinguishable) results at the molecular level. Mass spectrometry has also been used to detect $B$. anthracis, but the method lacks sensitivity [7]-[11]. Another drawback is that mass spectrometers are expensive, they are not portable, and the experiment cannot operate under atmospheric conditions. The infectious dose for $B$. anthracis has been reported to be approximately $10^{4}$ spores, and few rapid detection methods using mass spectrometry can detect spore counts below $10^{5} \mathrm{cfu} / \mathrm{mL}$ [12]. In contrast to IR and MS methods, microscopy and flow cytometry techniques do not provide data based on the chemical components of the microorganisms at the molecular level, thus they are more accurate and more commonly used.

In microscopy methods, by labeling the cells with a specific dye, it is possible to visualize and identify a wide range of bacteria. For example, Huang et al. [13] have successfully used fluorescence microscopy for the identification of $S$. tythimium cells. The detection limit of the technique was reported to be $10^{4} \mathrm{cfu} / \mathrm{mL}$, with a total 
Table 1. A list of pathogenic bacteria and related diseases [5].

\begin{tabular}{|c|c|}
\hline Bacterium & Site of infection/clinical syndrome \\
\hline Bacillus anthracis & anthrax \\
\hline Bacillus cereus & food poisoning/food-borne enteritis \\
\hline Bacteroides sp. & abdominal sepsis, abscesses (including cerebral) \\
\hline Bordetella pertussis & whooping cough \\
\hline Campylobacter sp. & food-borne enteritis \\
\hline Chlamydia pneumoniae & respiratory tract (atypical pneumonia) \\
\hline Chlamydia trachomatis & genital tract, eye \\
\hline Clostridium botulinum & botulism \\
\hline Clostridium difficile & antibiotic-associated diarrhea (inc pseudomembranous colitis) \\
\hline Clostridium perfringens & gas gangrene, abdominal sepsis, food poisoning \\
\hline Clostridium tetani & tetanus \\
\hline Corynebacterium diphtheriae & diphtheria \\
\hline other Corynebacterium sp. & urinary tract, "line” colonisation/infection \\
\hline Enterococcus spp. (formerly Streptococcus) & urinary tract, "line” colonisation/infection, abdominal sepsis \\
\hline Escherichia coli & urinary tract, abdominal sepsis, neonatal septicaemia/meningitis \\
\hline Haemophilus influenzae & non-capsulate: respiratory tract (inc exacerbation COAD, middle ear) \\
\hline Helicobacter pylori & atrophic gastritis, peptic ulcer disease \\
\hline Klebsiella sp. & urinary tract, abdominal sepsis \\
\hline Legionella pneumophila & Legionnaires disease (Pontiac fever, “atypical” pneumonia) \\
\hline Listeria monocytogenes & septicaemia/meningitis (esp neonates \& immunosuppressed) \\
\hline Moraxella catarrhalis & respiratory tract (inc exacerbation COAD, middle ear) \\
\hline Mycobacterium leprae & leprosy \\
\hline Mycobacterium tuberculosis & tuberculosis \\
\hline other Mycobacterium sp. & rarely tuberculosis, possibly other infections in immunosuppressed \\
\hline Mycoplasma pneumoniae & respiratory tract (“atypical” pneumonia) \\
\hline Neisseria gonorrhoeae & gonnorhoea \\
\hline Neisseria meningitidis & septicaemia/meningitis \\
\hline Proteus sp. & urinary tract, abdominal sepsis \\
\hline Pseudomonas aeruginosa & urinary tract, abdominal sepsis, respiratory tract in cystic fibrosis patients \\
\hline other Pseudomonas sp. & "line” colonisation/infection \\
\hline Salmonella typhi/paratyphi & typhoid fever \\
\hline other Salmonella sp. & food-borne enteritis \\
\hline Shigella sp. & food-borne enteritis \\
\hline Staphylococcus aureus & $\begin{array}{l}\text { skin \& soft tissue (eg abscess/cellulitis/fascitis), food poisoning \& } \\
\text { other toxin-mediated disease, endocarditis, osteomyelitis }\end{array}$ \\
\hline Staphylococcus epidermidis & "line” colonisation/infection ( \& other prostheses) \\
\hline Streptococcus agalactiae & neonatal septicaemia/meningitis \\
\hline Streptococcus pneumoniae & respiratory tract (including lobar pneumonia, exacerbation COAD, middle ear), meningitis \\
\hline Streptococcus pyogenes & $\begin{array}{l}\text { skin \& soft tissue (e.g. abscess/cellulitis/fascitis), pharyngitis } \\
\text { (rheumatic fever, glomerulonephritis) }\end{array}$ \\
\hline Streptococcus viridans & bacterial endocarditis \\
\hline Vibrio cholerae & food-borne enteritis including cholera \\
\hline
\end{tabular}


analysis time of 4 hours. Luminescence-based systems have also been used for the detection of bacteria in the environment [14]. This detection approach is based on the oxidation of luciferin followed by light emission using ATP. The emission of light is proportional to the ATP concentration, and the process is catalyzed by luciferase. Another interesting instrumental method is flow cytometry. Using a flow cytometer, cells are stained with a dye and injected into a stream of sheath fluid, and are kept at the center of the stream. The cells in the sample are accelerated and pass, individually, through a laser beam (see Figure 1).

When a cell passes through the laser beam, it deflects the incident light. Light scattered from the interaction between the cell particle and the laser beam is collected by a lens and directed to the optical detectors. The detectors convert the light into an electrical signal. The light scattering gives information about cell size, shape and structure. Forward-scattered light (FSC) is proportional to the surface area or size of a cell and side-scattered light (SSC) is proportional to the granularity or internal complexity of a cell [15] (see Figure 2).

Flow cytometry is a practical technique for bacteria counting in clinical, environmental and industrial microbiology [16]. In the past, disadvantages associated to this method have been high cost of the instrumentation/ analysis. However, the assays can be performed relatively rapidly and provide a solid ability to obtain quantitative results.

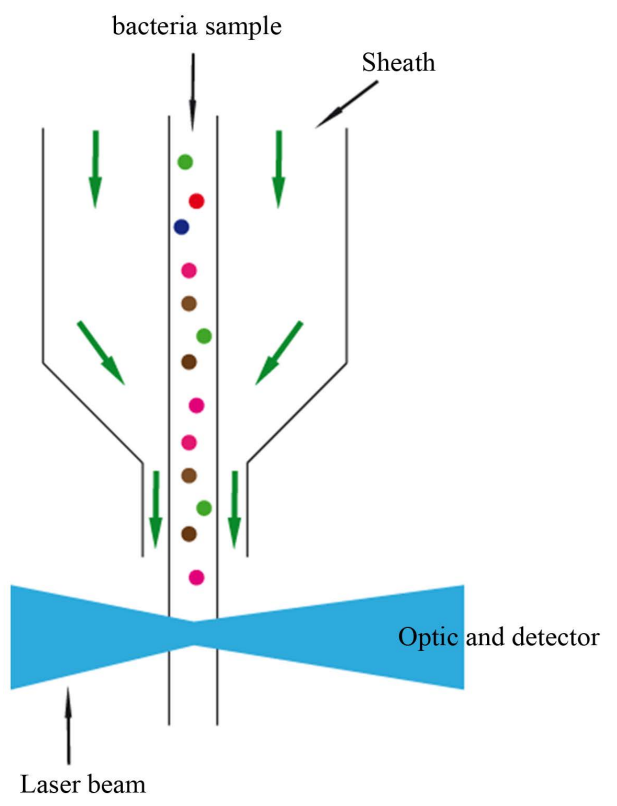

Figure 1. Schematic illustration of a flow cytometer.

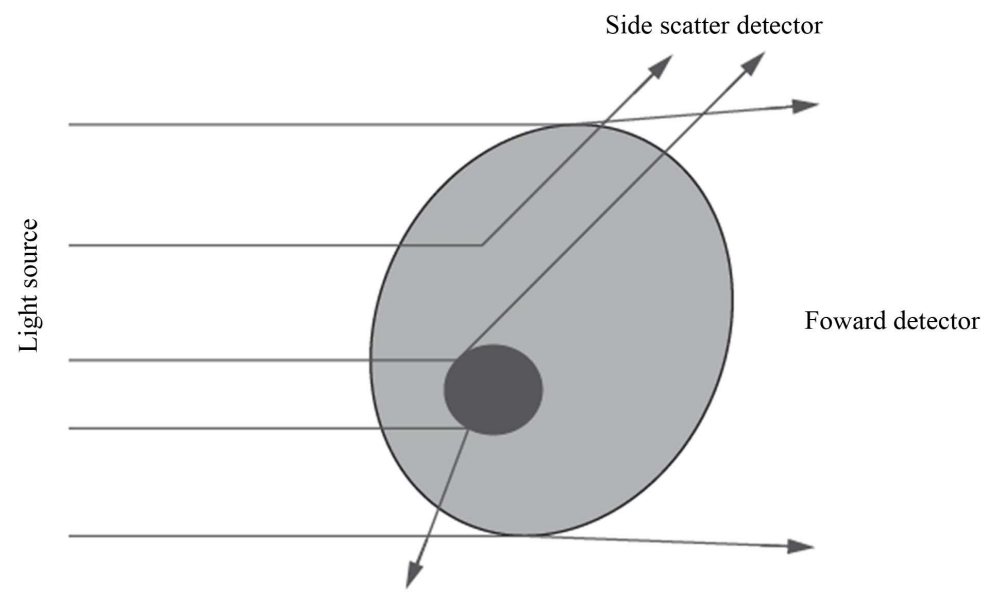

Figure 2. Light-scattering by a cell [15]. 
Wu et al. have demonstrated that flow cytometry used in conjunction with fluorescence microscopy, is a very efficient detection approach allowing to identify and quantify viable E. coli (using M13KE-TC labeled phages to recognize E. coli ER2738) [17]. Within 3 hours of measurement time, it was demonstrated that as few as $1 \%$ of viable $E$. coli cells could be quantified, in the presence of high concentrations $\left(10^{6} \mathrm{cells} / \mathrm{mL}\right)$ of non-viable (dead) and non-target bacteria.

\section{Biosensor-Based Detection Methods}

A biosensor is essentially an analytical device that integrates a biological/biochemical component with a physical transducer, for the detection of a specific analyte (or multiple analytes) present in a sample of interest [18]-[20]. The biological/biochemical species used for recognition purposes, usually referred to as probes, are wide ranging in nature (bacteriophages, cell receptors, enzymes, antibodies, nucleic acids, aptamers, etc.). The probe layer immobilized onto the transducer platform interacts/binds (recognizes) the taget analyte under study, and the interaction leads to a quantifiable signal. Biosensors are very versatile devices, their use has been extended to nanotechnological and nano-robotical applications [21] [22].

Depending on the method of signal transduction, biosensors can be classified into four major categories: optical, piezoelectric, electrochemical, and thermal sensors [23]. Each of these four sensor types can be adapted to perform either direct (label-free) or indirect (labelled) detection of target species. Efforts to commercialize biosensor technology are currently widespread, but progress in this area is still on-going due to problems that remain in achieving acceptable sensitivity and reproducibility. In the following section, the role of the most common biorecognition elements used in the construction of biosensors, and the improvements achieved by using optical, piezoelectric or electrochemical sensors for bacteria detection, are described. The most common biorecognition elements used in biosensor technology for the detection of bacteria are antibodies, nucleic acids, aptamers, and phages.

\subsection{Antibodies for Bacteria Biosensors}

Antibodies are used extensively as biorecognition elements. They can be used for pathogen detection or for detection of some of the pathogen components such as enzymes, toxins, pili, and spores. Based on the method of production, antibodies are categorized as polyclonal or monoclonal, monoclonal antibodies being the more specific and more expensive recognition elements. Antibodies can easily adsorb onto the transducer surface, or be immobilized by chemical conjugation or cross-linking onto the sensing surface through contact with functional groups such as amines and carboxylates.

Some publications have reported on the existence of peptides that are smaller than antibodies, that can specifically bind to pathogens [24]. The peptides can be produced from pathogen-binding proteins, they can also be synthesized in vitro following procedures similar to those used for aptamers. Fluorescent labelled peptides have been successfully used for the detection of bacterial toxin and spores [25]. Peptides have also been employed for the detection of different virus strains by ELISA and dot-plot assay [26].

\subsection{Nucleic Acids for Bacteria Biosensors}

Single-stranded nucleic acids can also be used as recognition elements to bind with complementary DNA or RNA sequences of a target microorganism. The oligonucleotides can be deposited onto the sensor surface by different means. For example, oligonucleotides modified with $\mathrm{NH}_{2}$ terminal groups (which are readily available commercially) can be attached to suitable functional groups at the surface of a transducer through covalent bonding [27], or oligonucleotides modified with $\mathrm{SH}_{2}$ terminal groups can be directly self-assembled onto gold surfaces [28].

\subsection{Aptamers for Bacteria Biosensors}

Aptamers, first reported on in 1990, are engineered nucleic acids that specifically bind to various targets of biological interest. The targets can be small molecules, peptides, proteins, nucleic acids or even whole cells. The advantage they offer over using antibodies or other alternative approaches is the simplicity associated with their production and isolation. They can be created completely in vitro by chemical synthesis, they are easy to store, and show non-immunogenicity in therapeutic applications [29]. Aptamers immobilized as probes are more resistive 
than antibodies to freezing and drying reconstituting cycles, but they have a higher sensitivity to enzymatic degradation. To date, work on aptamers has mainly been limited to therapeutic applications, nevertheless the number of publications on their integration with sensing devices is on the rise.

\subsection{Phages for Bacteria Biosensors}

Phages are bacterial viruses that bind to target bacteria through specific receptors present at the surface of host cells. They inject their genetic material inside the cells and use the cell machinery to replicate. The fact that phages are capable of targeting specific bacteria makes them attractive candidates for use as probes in sensor devices. A few papers have reported on the use of phages as recognition elements to detect bacteria using fluorescence microscopy [30], using acoustic wave biosensors [31], or impedance spectroscopy [32]. We are describing here in more detail the biology and structure of phages, since they have emerged as elite probes for the specific detection of bacteria. Bacteriophages are small viruses that recognize specific receptors on the bacterial surface, to which they bind and then proceed to inject their genetic material. These viruses recognize target bacteria through receptors located on their tail. The target host of each phage is often narrowed to one species of bacteria, but several related species can sometimes be infected by the same phage. In effect, it is now well accepted that interactions between phages and bacteria are highly specific. They are very abundant organisms on earth. They can be found in large numbers wherever their host bacteria exist, such as in the soil, in sewage and feces, and in water [33].

As in the case of other viruses, phages are absolute parasites. They have no ability to generate energy and they have no ribosomes to produce proteins. They inject/transfer all the information for their production to an appropriate host. Each phage converts an infected bacterium into a phage-manufacturing system, which yields a large number of phage progeny. The degree to which different phages use part of the genetic machinery of the host varies. Some phages have fewer than 10 genes and they are totally dependent on bacteria cells, while some other phages have 30 to 100 genes, and they are dependent on proteins encoded by their own genetic material [34].

Different types of phages vary in size and shape. The size of most phages ranges from 25 to $200 \mathrm{~nm}$, and the structure of the majority of phages is composed of a capsid (or head, which contains the genetic material), and a tail. The genetic material contains the nucleic acid genome (DNA or RNA) of the specific phage, covered by a protein coating which forms the capsid. The capsid is composed of many copies of different proteins which act to protect the genetic material from harmful substances. The tail is a hollow tube surrounded by a contractile sheath through which the nucleic acid passes and ends up being injected into the bacteria. At the end of the tail, there is a base plate and fibers, which enable phages to bind to the bacteria cells. It should be reiterated however that not all phages possess the tail and sheath [33]. The structure of phage T4 is shown (see Figure 3) as a model system.

Two categories of bacteriophages have been identified: lytic and temperate phages. Based on these categories, the phage follows either the lytic or lysogenic life cycle. In the lytic cycle, the phage converts a bacteria host cell into a phage factory to produce more phages, effectively destroying the bacteria (lysis), and releasing newly produced phages for the infection of other hosts. The lysogenic cycle on the other hand, is typically observed with phages containing double-stranded DNA. In this case, the phage DNA attaches itself to the host chromosome and leads to the formation of a new set of phage called a prophage. Virulent phages such as T4 usually lyse and destroy the host cells, while temperate phages, such as phage lambda, can adopt either the lytic or the lysogenic cycle.

The key factor dictating whether the lytic or the lysogenic pathway becomes operational is the relative expression rates of the phage repressor encoded by the cII gene (which promotes lysogeny) and the cro protein, to be able to switch off the expression of the repressor gene and initiate the lytic pathway [34]. For example, after infection of the host cells by phage lambda, a small proportion of these phages adopt the lytic pathway, while the majority of the phages enter the lysogenic cyle. These phages continue to replicate and produce clones of themselves containing phage DNA, and prevent further infection of bacteria.

\section{Different Types of Biosensors}

In order to detect bacteria efficiently, the analytical device needs to meet certain requirements that are outlined in Table 2. They should be able to specifically detect different types of bacteria, they should be able to distinguish between live and dead bacteria, their operation/manipulation should be simple and more importantly, they 


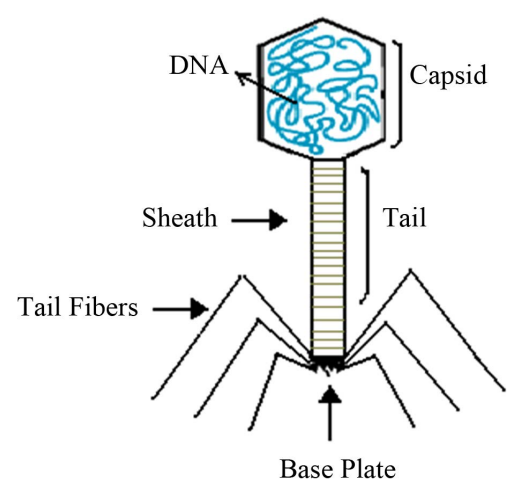

Figure 3. Structure of phage T4.

Table 2. Biosensor characteristics for bacteria detection [35].

\begin{tabular}{cc}
\hline \multicolumn{2}{c}{ Sensor Characteristic for Bacterial Detection } \\
\hline $\begin{array}{c}\text { Low detection limit } \\
\text { Assay time }\end{array}$ & Ability to detect single bacteria \\
Assay protocol & $5-10$ min for a single test \\
Measurement & No reagent addition needed \\
Format & Direct, without pre-enrichment \\
Operator & Highly automated format \\
Viable cell count & Minimum skill required to use the assay \\
Size & Should discriminate between live and dead cells \\
Species selectivity & Compact, hand-held \\
\end{tabular}

should be sensitive. As mentioned previously, the main categories of biosensors are based on optical, piezoelectric, electrochemical and thermal means of detection. In the following section, these techniques are described in relation to the detection of bacteria.

\subsection{Optical Biosensors}

Optical biosensors consist of a receptor immobilized onto a transducer, which enables the measurement of variations in light absorption/emission, refractive index, or thickness of a layer upon binding of the bacteria. Fluorimetry, surface plasmon resonance (SPR), functionalized optical fibers, and interferometry, are examples of techniques that have been adapted to bacteria detection.

An instrument based on fluorimetric detection, the AVL BDS-240, is a non-invasive automated system for the rapid detection of bacteria as well as some fungi. This instrument has an optical unit consisting of a filtered excitation source and a photodiode detection system. Since $\mathrm{CO}_{2}$ is a product of bacteria metabolism, $\mathrm{CO}_{2}$ optical sensors have been chosen to detect bacteria in human blood. During the bacteria's metabolic process, the $\mathrm{CO}_{2}$ concentration increases, causing a change in fluorescence emission from a colorimetric $\mathrm{pH}$ indicator added to the sample [36].

An evanescent wave interferometer was also used to detect Salmonella typhmurium species [37]. In this case, a laser beam is directed into a wave guiding film and the light passes through the surface of the chip. The surface area functionalized with a specific receptor thus becomes the sensitive part of the chip. This system enabled the detection of $10^{8}-10^{10}$ cells/mL within 5 minutes. Although the system has a short detection time, it has a poor sensitivity.

More recently, surface plasmon resonance (SPR), is an optical technique that has been widely used for the detection of bacteria. A light beam is directed onto a metal film such as gold or silver at a fixed angle corresponding to what is called the resonance angle, oscillations of the free electrons at the metal surface (surface 
plasmons) are induced, which generate a sensitive area on the surface called an evanescent field [38]. When the immobilized probe molecules bind to the targeted species, a variation in the surface plasmon oscillation frequency occurs, which is directly proportional to the change in the amount of bound, or adsorbed target (see Figure 4). The binding is detected by measuring the ensuing changes in the refractive index. A collimated polychromatic light beam is directed onto the prism at a specific angle and excites surface plasmon waves at the metal/dielectric interface. The binding of bacteria to the antibodies immobilized onto the gold film causes a change in the refractive index [39].

The first application of an SPR sensor for the detection of bacteria was reported by Fratamico et al. [40]. A sandwich assay was used to detect $E$. coli O157:H7 cells. A monoclonal antibody was immobilized onto the surface to capture the bacteria, and the captured bacteria were then further probed by a secondary antibody to increase the signal. No significant signal was observed using other (non-target) types of bacteria such as $S$. typhmurium or $Y$. enterocolitica. The sensor was able to detect $10^{7}$ cells $/ \mathrm{mL}$, and the surface could be regenerated and reused for 50 measurements.

Numerous works based on using SPR for sensing purposes, and their corresponding limits of detection, have been reported. Obviously, many factors such as the efficiency of probe immobilization, or sample treatment methods, will have an effect on the detection limit of the system. In one study, Taylor et al. compared the observed detection limits for different sample treatment methods for the detection of E. coli O157:H7, and found the following: $10^{7} \mathrm{cfu} / \mathrm{mL}$ for an untreated live sample, $10^{6} \mathrm{cfu} / \mathrm{mL}$ for a heat-killed sample, $10^{6} \mathrm{cfu} / \mathrm{mL}$ for a heatkilled and ethanol soaked sample, and $10^{5} \mathrm{cfu} / \mathrm{mL}$ for a heat-killed and detergent lysed sample [39]. The difference in detection limits can be explained by the change in size and morphology of the cells. For heat-killed samples, E. coli O157:H7 cells can either change from their rod shape to become spherical, or be broken up into smaller pieces. Lysis also breaks up the cells, creating smaller pieces and increasing the concentration of detectable material. This facilitates mass transport, allowing material to more easily reach the sensor surface, therefore improving the overall sensitivity.

Usually, SPR sensors have been known to have high detection limits for the analysis of bacteria. This problem has been mainly attributed to the large dimensions of bacteria cells. Since detection with the SPR sensor depends on the ability of the analyte to reach the immobilized receptor at the surface, the large size of bacteria can make diffusion to the surface slow and limit the sensor response. However, in recent years major progress has been made in the development of SPR-based approach to detection of pathogenic bacteria. SPR has been demonstrated to be a very effective method to detect and quantify E. coli O157:H7 and methicillin-resistant Staphylococcus aureaus (MRSA) [41]-[43]. The detection is based on the specific detection of the penicillin binding protein, PBP2a. The measurements allow discrimination between the MRSA, and MSSA (methicillin-sensitive Staphylococcus aureaus) or BORSA (borderline oxacillin-resistant Staphylococcus aureaus), within 20 minutes, and at concentrations of $10 \mathrm{cfu} / \mathrm{mL}$.

Optical fibres represent another interesting technology that has been adapted to the detection of bacteria. The structure of an optic fibre consists of polystyrene or silica glass with dopants such as $\mathrm{Al}_{2} \mathrm{O}_{3}, \mathrm{~B}_{2} \mathrm{O}_{3}, \mathrm{GeO}_{2}$. These dopants act to modify the optical properties of the fibres by raising their refractive index [44]. An optical fibre is composed of two main components: 1) the core with higher refractive index and 2) the cladding with lower

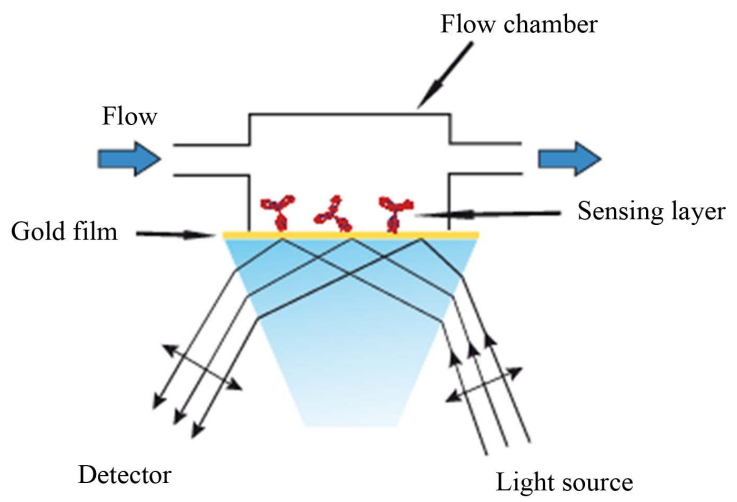

Figure 4. Simplified schematic of an SPR sensor. 
refractive index. At a specific angle, incident light is transmitted through the optical fibre by total internal reflection, and a photo-detector can be used to capture the light either at the end of the fibre or at the cladding.

Ko et al. have used an optical fibre-based approach for the detection of S. typhmurium in ground beef [45]. Their fibres were functionalized using a silanization method, and labelled antibody-protein $G$ complexes were then immobilized onto the cladding to form the evanescent wave-sensing region. The modified optic fibre was immersed into homogeneous ground beef containing Salmonella and the detection limit was determined to be $10^{5} \mathrm{cfu} / \mathrm{g}$, with measurements taking 5 minutes. Geng et al. have demonstrated the use of optical fibers for the detection of Listeria monocytogen cells in hot-dog or bologna [46]. In this sensor, polyclonal antibodies were immobilized onto polystyrene optic fibers through biotin-streptavidin chemistry. This immunosensor was tested with other (non-target) bacteria and showed good specificity toward the Listeria monocytogen species. The sensitivity of the sensor was $10^{3} \mathrm{cfu} / \mathrm{mL}$ in pure culture grown at $37^{\circ} \mathrm{C}$. After enrichment steps, it took approximately 24 hours to detect bacteria cells in hot-dog samples, with a detection limit of 10 to $10^{3} \mathrm{cfu} / \mathrm{g}$. In another report a fiber optic chemiluminescence biosensor, coupled with a magnetic separation system, was used for the detection of $E$. coli O157:H7 in inoculated food samples including chicken, beef, and vegetables [47]. Briefly, a sandwich immunoassay consisting of $E$. coli-antibody coated magnetic beads, E. coli cells, and horseradish peroxidase (HRP)-labelled anti-E. coli coated magnetic beads, was formed. The bacteria cells were detected by collecting, through use of a fiber optic, the HRP-catalyzed chemiluminescence emanating from the surface of the beads. The advantage of this approach is its low detection limit $\left(10^{2} \mathrm{cfu} / \mathrm{mL}\right)$, without any need of an enrichment step, with a detection time of 1.5 hours.

\subsection{Piezoelectric Biosensors}

Piezoelectric biosensor devices are generally prepared by coating a piezoelectric transducer surface with a receptor, such as antibodies, followed by binding with bacteria. As the bacteria bind to the receptors, the mass at the surface of the piezo-sensor changes, and this is reflected by a variation of the piezoelectric crystal's resonance oscillation frequency. The most widely used piezoelectric material is quartz because it is easily available and has good thermal stability. Piezoelectric technology has been used for the detection of a variety of microorganisms, with a wide range of applications in the food industry, the environment, clinical diagnosis, and biotechnology in general [48] [49].

The detection of $S$. enteritideis is one example of the use of a piezoelectric device for the detection of bacteria [50]. In this sensor a piezoelectric crystal covered with layers of gold, silver, and palladium was then coated with polyethyleneimine to immobilize antibodies, allowing for recognition of the $S$. enteritideis species. Binding of the bacteria resulted in measurable changes in the crystal's resonance frequency parameter, giving a detection limit of $10^{5} \mathrm{cfu} / \mathrm{mL}$, with a detection time of 35 minutes. In other work, S. typhmurium was detected using a polyclonal antibody immobilized by the Langmuir-Blodgett method onto the surface of a quartz acoustic wave sensor [51]. The detection limit of this sensor was found to be a few hundred cells $/ \mathrm{mL}$, with a response time of less than $100 \mathrm{~s}$ over the range of $10^{2}-10^{10}$ cells $/ \mathrm{mL}$. The sensor's response was found to be linear with bacterial concentrations ranging from $10^{2}$ to $10^{7}$ cells/mL.

Another piezoelectric crystal sensor using antibodies has been developed for the detection of Salmonella, E. coli, Shigella, and Yersiniapestis [52]. In this case, crystals coated with antibodies were immersed in bacteriacontaining solution for 45 minutes and, after washing and drying steps, the shift in resonance frequency was measured. A linear response was observed in the concentration range of $10^{6}-10^{8} \mathrm{cfu} / \mathrm{mL}$ and the authors reported that the sensor could be reused at least 12 times. In another effort, a piezoelectric device was used to detect bacteria cells in drinking water [53]. For this purpose, anti-E. coli were immobilized onto crystals and used to detect $E$. coli K12. An identical crystal (not modified with anti-E. coli) was dipped in the same bacteriacontaining solution to act as reference. The resonance frequency was measured as a function of $E$. coli concentration. The response range was found to be $10^{6}-10^{9} \mathrm{cfu} / \mathrm{mL}$. In this case it was not possible to regenerate the sensing surface. Attempts to remove the bound bacteria by washing the crystal with urea or glycine-HCl buffer resulted not only in removing the bacteria, but also the antibodies, therefore making reuse impossible. Other similar approaches were used for bacteria detection such as the quartz crystal microbalance (QCM) for the detection of S. typhmurium [54], or the detection of Chlamydia trachomatis in urine samples [55].

The main disadvantage with piezoelectric biosensors is the numerous washing and drying steps involved and the regeneration of the sensing surface layer. However, the problem of regeneration can be solved by manufac- 
turing small crystals at low cost, therefore making the devices disposable, but these sensors may suffer from lack of sensitivity.

\subsection{Electrochemical Biosensors (Amperometric, Potentiometric, and Impedimetric)}

Electrochemical biosensors have some advantages over optical sensors. They are generally more sensitive, the equipment required for analysis is less complicated and less expensive. The electrochemical sensing electrodes are also well suited to miniaturization, making possible the development of small, portable, and potentially disposable sensors. Amperometry/conductometry, potentiometry and impedimetry are the main electrochemical methods used for biosensor applications to bacterial detection.

\subsubsection{Amperometric Sensors}

Amperometric biosensors typically rely on an enzyme system that catalytically converts electrochemically nonactive analytes into products that can be oxidized or reduced at a working electrode. The measurement is based on the variation in current as a function of applied potential. Neufeld et al. have reported on an amperometric method based on enzyme activity [56]. A bacteriophage is used to infect the bacteria species, causing the release of intracellular enzymes, and the activity of these enzymes is measured amperometrically. The product of the reaction between the enzyme and the substrate ( $p$-aminophenyl- $\beta$-D-galactopyranoside) is $p$-aminophenol, which is then oxidized at a carbon electrode and the resulting current is monitored as a function of time. With this method Staphylococcus and E. coli cells were detected with a detection limit of 1 cell/100mL, within a period of 6 to 8 hours. Brooks et al. have developed an enzyme-linked amperometric method for the detection of $S$. aureus with a detection limit of $10^{4}-10^{5} \mathrm{cfu} / \mathrm{mL}$ [57]. However, because of variations in the signals produced by the electrochemical detection step, this immunosensor suffered from lack of reproducibility.

Gehring et al. [58], employed an immunomagnetic separation system to electrochemically detect Salmonella species. In this method a sandwich immunoassay was formed using super-paramagnetic beads coated with antiSalmonella and anti-Salmonella antibodies linked with alkaline phosphate. The complex immunoassay was performed by lowering the surface of graphite ink strip electrodes into the sample using a magnet, and voltammetry (current measured versus applied voltage) was used to detect the bacterial cells. This system was able to detect $10^{3}$ $\mathrm{cfu} / \mathrm{mL}$ within $80 \mathrm{~min}$.

\subsubsection{Potentiometric Sensors}

Potentiometric biosensors are another type of electrochemical sensor, which measures the variation in potential that occurs when the analyte molecules interact with the probe-modified surface. In past years, an electrochemical approach using light addressable potentiometric sensors (LAPS), has been successfully used for the detection of pathogens. A LAPS is made up of a semiconductor chip (n-type silicon), covered with a silicon-dioxide insulating layer, placed in contact with the sample solution. The potential that results from the different charge distributions that exist at the insulating layer/solution interface and the semiconductor/insulator interface, is directly influenced by the binding interactions occurring at the probe-modified insulating layer surface, and the signal is enhanced by illumination with a modulated light beam [48].

Gehring et al. have also developed a LAPS system for the detection of E. coli O157:H7 cells in food samples using a polyclonal antibody as probe. Their system was able to detect $10^{3}$ cells $/ \mathrm{mL}$ [59]. The LAPS approach has also been used to detect $E$. coli $D H 5 \alpha$ in drinking water [60]. A glass cover slip was coated with primary anti-E. coli using a silanization method. $E$. coli in the drinking water was captured by the primary immobilized antibody, and then a secondary urease-E. coli antibody conjugate was used to link with the captured E. coli. The sample chamber was then washed with PBS, then urea was fluxed through the chamber and the reaction monitored. Urea is enzymatically converted to ammonia in proportion to the amount of bacteria cells initially present in the sample. The production of ammonia causes a change in the redox potential which is measured. The authors have reported that this system allows the detection of 10 cells/mL. Although the LAPS technique offers improvements over the more conventional methods of potentiometric detection of bacteria, there still remain issues in terms of reproducibility.

\subsubsection{Impedimetric Sensors}

In recent years, electrochemical transduction based on impedance techniques has received increasing attention 
for applications in biological and biomedical detection. This is due to a number of factors such as: 1) impedance is one of the most important techniques for direct (label-free), real time detection; 2) the electrical properties of biological cells make them attractive analytes for detection using impedance-based methods; 3) impedance as an electronic detection system allows for the development/use of miniaturized biosensors (biochips), effectively providing access to smaller analytical devices rather than having to resort to using more cumbersome laboratorybased instruments [61].

The simplest impedance method for identification and quantification of bacteria is growth monitoring, which is based on the changes of impedance or conductance due to actual growth of bacteria, or a reaction resulting from the bacterial growth [62] [63]. Impedance microbiology is the basis for existing commercial impedimetric systems such as Bactometer ${ }^{\circledR}$ from Biomerieux, Bactrac ${ }^{\circledR}$ from Sy-Lab, and RABIT $®$ from Don Whitley Scientific [64].

An important mechanism for detection based on growth makes use of the metabolic activity of the biological cells. The change in impedance is mainly caused by the release of ionic metabolites into the culture medium, as prescribed by the energetics of the live cell metabolism, which can be summarized as the consumption of oxygen and sugars by the bacteria and the generation of carbon dioxide and organic acids. For instance, a non-ionized glucose converted to two molecules of lactic acid lead to an increase in the conductivity of the medium. Furthermore, the metabolically driven combination of lactic acid with oxygen leads to the formation of carbonic acid, yielding more mobile carbonate ions and increased conductivity. Another contributing factor to changes in impedance is the possible ion exchange across the cell membrane. Ions such as $\mathrm{K}^{+}$and $\mathrm{Na}^{+}$are known to pass through ion channels in the cell membrane, which serves to adjust the osmotic difference between the interior and exterior of the cells [65]. Ion exchange causes changes in the ionic composition of the surrounding medium and therefore changes its electrical conductivity.

Even though growth-based impedance techniques are reliable and enable the detection of viable cells, they still suffer from high detection times and non-specificity. Usually, low cell numbers take a long time to grow (up to 24 hours) and the method cannot be used to identify specific strains of bacteria. Therefore, antibodies, nucleic acids, aptamers, peptides, and more currently phages, are being used consistently as probes for specific binding to target pathogens. Recent advances in the area of bacteria detection have been made by using electrochemical impedance spectroscopy (EIS). Most impedance biosensors for bacteria detection are based on using the electrically insulating properties of the cell membrane. When the cells attach to an electrode surface, the electrode surface area gradually gets covered with matter that reduces conductivity and therefore changes the impedance at the interface.

To obtain an impedance signal, the measurement can be performed in the presence or absence of redox couples such as $\left[\mathrm{Fe}(\mathrm{CN})_{6}\right]^{3-/ 4-}$, which are referred to as faradaic or non-faradaic impedance measurement conditions, respectively [66]. Among the various recognition elements that were discussed previously, antibodies are the most commonly used bioreceptor for bacteria detection. Sensors based on the immobilization of antibodies require the attachment of a certain amount of bacteria cells to the electrode surface to produce a detectable signal. When antibodies are used as probes, two types of detection processes can be distinguished: 1) in the presence of a redox couple, the detection signal corresponds to changes in the faradaic impedance due to the biological events occurring on the surface, and 2) in the absence of a redox couple, the signal relates directly to the physical attachment of bacteria cells at the sensor surface, and the electrically insulating properties of the cell membrane [67]. Two important parameters to be considered when using EIS biosensors are the interfacial capacitance, also called the double-layer capacitance $\left(\mathrm{C}_{\mathrm{dl}}\right)$, and charge-transfer resistance $\left(\mathrm{R}_{\mathrm{ct}}\right)$ at the electrode surface. In certain applications, however, the key parameter of interest for detection purposes can be the conductivity of the medium (changes in solution resistance) [68].

\section{1) Faradaic impedimetric biosensors}

There are now several reports on the impedimetric detection of pathogens in media containing a redox active species, typically the $\left[\mathrm{Fe}(\mathrm{CN})_{6}\right]^{3-/ 4-}$ redox couple. The detection here is based on measuring variations of the charge-transfer resistance $\left(\mathrm{R}_{\mathrm{ct}}\right)$ at the electrode surface, upon attachment of bacterial cells. Ruan et al. have reported on an electrochemical immunosensor for the detection of $E$. coli O157:H7, using $\left[\mathrm{Fe}(\mathrm{CN})_{6}\right]^{3-/ 4-}$ as the electroactive redox couple in solution [69]. In this biosensor, anti-E. coli antibodies were immobilized onto a planner indium-tin oxide (ITO) electrode surface and used to detect E. coli cells. The sensor used secondary antibodies conjugated with horseradish peroxidase to generate insoluble products at the electrode surface. These insoluble products then act to prevent electron transfer at the surface and therefore cause a detectable variation 
in impedance.

The overall biosensing system can be interpreted by an equivalent circuit as illustrated in Figure 5(a). The proposed equivalent circuit includes the resistance of the electrolyte $\left(R_{s}\right)$, the double-layer capacitance $\left(C_{d l}\right)$, the charge (electron) transfer resistance $\left(\mathrm{R}_{\mathrm{ct}}\right)$, and the Warburg impedance $\left(\mathrm{Z}_{\mathrm{w}}\right)$. Figure $5(\mathrm{~b})$ shows a typical Nyquist plot of the imaginary impedance $\left(\mathrm{Z}_{\mathrm{im}}\right)$ versus the real impedance $\left(\mathrm{Z}_{\mathrm{re}}\right)$, measured over a range of applied ac voltage frequency, which shows a combination of a semicircle and a straight line [66] (Bard and Faulkner, 2001). The semicircle relates to the faster electron-transfer processes occurring at the electrode surface (it appears in the high frequency domain of the Nyquist plot), while the straight line relates to the diffusion limited, mass transfer, processes that occur near the electrode on the solution side of the interface (it appears in the low frequency domain). The intercept of the semicircle with the $\mathrm{Z}_{\mathrm{re}}$ axis at high frequency yields the value of $\mathrm{R}_{\mathrm{s}}$, and the diameter of the semicircle is equal to $\mathrm{R}_{\mathrm{ct}}$.

Among the various parameters present in the equivalent circuit, the electron transfer resistance, $R_{c t}$, was identified by Ruan et al. [69], as the main parameter being influenced by the binding of E. coli. After E. coli binding, the interfacial electron-transfer kinetics slow down and increase the electron transfer resistance. The increase in $\mathrm{R}_{\mathrm{ct}}$ can be explained as bound cells inhibiting electron transfer between the electrode and he $\left[\mathrm{Fe}(\mathrm{CN})_{6}\right]^{3-/ 4-}$ redox couple in solution. Ruan et al. showed that the value of $\mathrm{R}_{\mathrm{ct}}$ increased with increasing bacteria concentration. This biosensor showed a linear response in the concentration range of $10^{4}$ to $10^{7} \mathrm{cfu} / \mathrm{mL}$, with a detection limit of $10^{2} \mathrm{cfu} / \mathrm{mL}$.

Another example of a label-free electrochemical impedance sensor using a redox couple was reported by Yang and coworkers [70]. They developed an immunosensor for the detection of E. coli O157:H7, using interdigitated array microelectrodes (IDA). The sensing surface consists of indium-tin-oxide (ITO) modified with antiE. coli antibodies. The antibodies were attached to the surface covalently through bonding between the carboxyl groups on the antibodies and the reactive hydroxyl groups on the ITO surface. The sample containing the target bacteria, in presence of the $\left[\mathrm{Fe}(\mathrm{CN})_{6}\right]^{3-/ 4-}$ redox couple, was then deposited onto the functionalized microelectrode array. When the bacteria bind to the surface, they prevent the electron transfer between the interdigitated electrodes and increase the electron transfer resistance (Figure 6).

A linear dependence of the charge transfer resistance on the logarithm of bacterial concentration was observed in the range of $10^{5}$ to $10^{8} \mathrm{cfu} / \mathrm{mL}$, with a detection limit of $10^{6} \mathrm{cfu} / \mathrm{mL}$. The detection limit for this approach is higher than that reported for the system used by Ruan et al. [69], or even for ELISA, but it is comparable to other immunosensor (antibody)-based methods using the quartz crystal microbalance (QCM) for the detection of Salmonella (with a detection limit of $10^{6} \mathrm{cfu} / \mathrm{mL}$ ) [71], and surface plasmon resonance (SPR) for the detection of Salmonella enteritidis and L. monocytogens (with a detection limit of $10^{6} \mathrm{cfu} / \mathrm{mL}$ ) [72], or the detection of $E$. coli O157:H7 (with a detection limit of $10^{6} \mathrm{cfu} / \mathrm{mL}$ ) [73].

\section{2) Non-Faradaic impedimetric biosensors}

Non-Faradaic impedance measurements mainly detect the attachment of bacterial cells onto the electrode surface, in the absence of a redox couple in the sample solution. Radke and Alocilja have developed one such impedance sensor for the detection of E. coli O157:H7 [74]. The sensor was made using a high-density gold interdigitated microelectrode array, with 1700 finger electrodes. Each electrode was $3 \mu \mathrm{m}$ in width and their separation was $4 \mu \mathrm{m}$, therefore providing a large sensing area. The gold microelectrode array was functionalized using 3-mercaptomethyldimethyl-ethoxysilane (MDS) followed by $N$-y-maleimidobutryloxy-succinimide ester

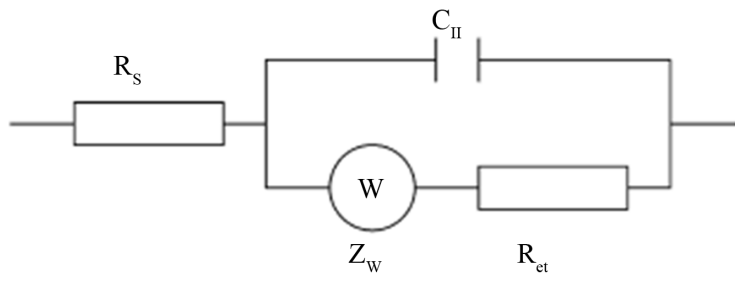

(a)

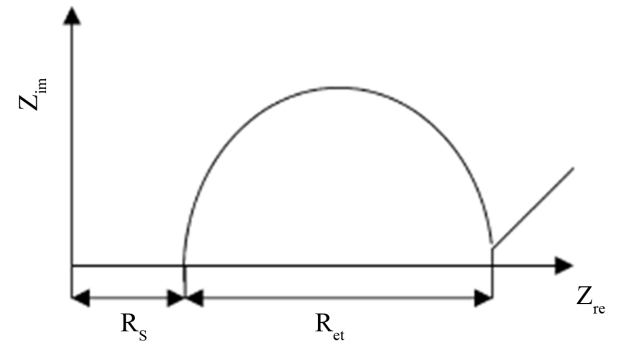

(b)

Figure 5. General equivalent circuit for an electrochemical cell in the presence of a redox couple (a). A typical Nyquist plot $\left(\mathrm{Z}_{\mathrm{im}}\right.$ vs $\mathrm{Z}_{\mathrm{re}}$ ) (b) used for the detection of $E$. coli O157:H7 cells. 


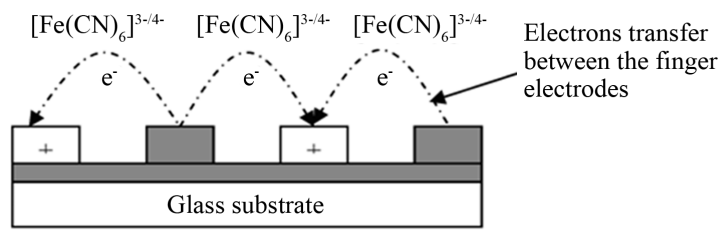

(a)

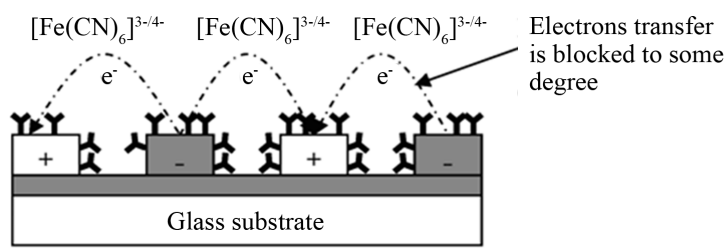

(b)

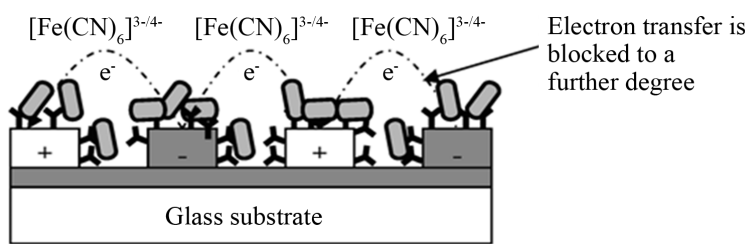

(c)

Figure 6. Direct impedimetric detection using interdigitated microelectrode arrays: (a) bare electrode; (b) with immobilized antibody; (c) with bound bacteria cells. The gray ovals are the E. coli O157:H7 cells; the Y shapes are the anti-E. coli antibody [70].

(GMBS) acting as a cross-linker. Anti-E. coli were then immobilized onto the surface to detect bacteria cells. After immersing the sensor into the bacteria-containing solution, an increase in impedance was observed over the frequency range of $100 \mathrm{~Hz}-10 \mathrm{MHz}$. The increase in impedance was attributed to the binding of the cells to the electrode surface (hence due to the electrically insulating property of their cell membrane). The sensor had a dose response to $E$. coli concentration from $10^{4} \mathrm{cfu} / \mathrm{mL}$ to $10^{7} \mathrm{cfu} / \mathrm{mL}$.

Some researchers have developed impedimetric biosensors using microfluidic chips. An example of this type of sensor was reported by Boehm et al. for the detection of E. coli cells [75]. Antibodies were immobilized onto the glass surface of a microfluidic chamber, and the bacteria-containing solution was passed through the chamber causing the $E$. coli to be captured by antibodies, resulting in an increase of the measured impedance. The detection limit of this sensor was found to be $10^{4} \mathrm{cfu} / \mathrm{mL}$. In microfluidic-based sensors, injected bacteria cells tend to accumulate inside the chamber and enhance the signal, which is favorable to the detection of low bacteria concentrations.

In the last few years, work has been done on the development of electrochemical sensors using microelectrode arrays, potentially allowing multiplex detection of pathogenic bacteria. Previous studies performed with our group of collaborators has demonstrated the feasabilaty of disposable microelectrodes and chemistries electrografting of biomolecules for "biosensing" detection of pathogenic bacteria, based on the use of immobilized bacteriophages (acting as probes ) on screen printed carbon. These phages have both a very high specificity for their bacterial targets have extreme stability in lyophilized or immobilized form, and there is no danger of contamination to humans.

For example, a novel method was presented for the specific and direct detection of bacteria using bacteriophages as recognition receptors immobilized covalently onto functionalized screen-printed carbon electrode (SPE) microarrays by Shabani et al. [32]. The SPE networks were functionalized through electrochemical oxidation in acidic media of 1-ethyl-3-(3-dimethylaminopropyl)-carbodiimide (EDC) by applying a potential of $+2.2 \mathrm{~V}$ to the working electrode. Immobilization of T4 bacteriophage onto the SPEs was achieved via EDC by formation of amide bonds between the protein coating of the phage and the electrochemically generated carboxylic groups at the carbon surface. The surface functionalization with EDC, and the binding of phages, was verified by time-of-flight secondary ion mass spectrometry. The immobilized T4 phages were then used to specifi- 
cally detect $E$. coli bacteria. The presence of surface bound bacteria was verified by scanning electron and fluorescence microscopies. Impedance measurements (Nyquist plots) show shifts of the order of $10^{4} \mathrm{Ohms}$ due to the binding of $E$. coli bacteria to the T4 phages. No significant change in impedance was observed for control experiments using immobilized T4 phage in the presence of Salmonella. Impedance variations as a function of incubation time show a maximum shift after 20 minutes, indicating onset of lysis, as also confirmed by fluorescence microscopy. Concentration-response curves yield a detection limit of $10^{4} \mathrm{cfu} / \mathrm{mL}$ for $50 \mu \mathrm{L}$ samples.

In another work [76], the carbon electrodes were initially functionalized through cyclic-voltammetric reduction of a nitro-aryl diazonium moiety, followed by further reduction of nitro groups to amino groups, and finally by treatment with glutaraldehyde. Functionalization of the carbon electrodes and the binding of Gamma phage were verified by X-ray photoelectron spectroscopy and time-of-flight secondary ion mass spectrometry, respectively. The Gamma phage-modified microarrays were then used to detect B. anthracis Sterne bacteria in aqueous electrolyte media. Faradaic impedimetric detection of bacteria in $\mathrm{KCl}$ solution containing the $\left[\mathrm{Fe}(\mathrm{CN})_{6}\right]^{3-/ 4-}$ redox couple shows a gradual increase in $\mathrm{Z}_{\mathrm{re}}$ values, taken from the extrapolation of the linear portion of Nyquist plots in the low frequency range, for sensors placed in contact with increasing concentrations of $B$. anthracis. $\Delta Z_{\text {re }}$ values vary approximately from 700 to 5300 Ohms for bacteria concentrations ranging from $10^{2}$ to $10^{8}$ $\mathrm{cfu} / \mathrm{mL}$, respectively. These shifts in $\mathrm{Z}_{\mathrm{re}}$ were attributed to a decrease in diffusion controlled charge transport to the electrode surface, which is related to the mass transfer-dependent component of the equivalent circuit $\left(Z_{w}\right.$ in Figure 5(a)), following capture of intact $B$. anthracis. No comparatively significant change in impedance was observed for control experiments using E. coli K12 as a non-specific target, even at a concentration of $10^{8}$ $\mathrm{cfu} / \mathrm{mL}$. Concentration-response curves yield a detection limit of $10^{3} \mathrm{cfu} / \mathrm{mL}$ for $40 \mu \mathrm{L}$ samples. The possibility of reducing the detection time and detection limit of the system was demonstrated by integrating the impedance sensor with a magnetic bead manipulation system [77]. Also, the ability of the magnetic bead approach to effectively isolate/remove and detect specific bacteria in a more complex sample (milk), was demonstrated.

In general, impedimetric systems possess the versatility for the development and commercialization of biosensors for the direct (label-free), and simultaneous detection (multiplexed), of different bacteria present in a single sample. However, some characteristics that still deserve further attention are sensitivity and overall performance in more complex media.

\section{Concluding Remarks}

A range of methods that can be used for bacteria detection were reviewed, pointing out their limitations and advantages. Although conventional methods remain reliable, the development of novel biosensor technologies is expanding with the hope of providing more rapid, specific, and convenient/reliable methods for bacteria identification. Different types of biosensors based on the use of different transducers were described, with emphasis being placed on optical and electrochemical biosensors because of their growing use and simplicity of operation. Surface plasmon resonance and impedimetric sensors, have now emerged as excellent candidates to fulfill the current needs in the area of specific and rapid detection of bacteria, for preventative and therapeutic applications. Impedimetric sensors, in particular, carry the potential to meet and resolve additional technological concerns related to biosensor miniaturization and portability. It should be noted however, that single cell detection still remains a daunting challenge. Since the infectious dosage of pathogens such as Salmonella or E. coli O157:H7 is 10 cells/100mL, the biosensor should be able to detect as low as one bacteria, with a rapid analysis time and low cost.

\section{References}

[1] Rowe, P.C., Orrbine, E., Lior, H., Wells, G.A., Yetisir, E., Clulow, M. and McLaine, P.N. (1998) Risk of Hemolytic Uremic Syndrome after Sporadic Escherichia coli O157:H7 Infection: Results of a Canadian Collaborative Study. The Journal of Pediatrics, 132, 777-782. http://dx.doi.org/10.1016/S0022-3476(98)70303-8

[2] Deisingh, A.K. and Thompson, M. (2002) Detection of Infectious and Toxigenic Bacteria. The Analyst, 127, 567-581. http://dx.doi.org/10.1039/b109895k

[3] Shangkuan, Y.-H. and Lin, H.-C. (1998) Application of Random Amplified Polymorphic DNA Analysis to Differentiate Strains of Salmonella typhi and Other Salmonella species. Journal of Applied Microbiology, 85, 693-702. http://dx.doi.org/10.1111/j.1365-2672.1998.00582.x

[4] Ivnitski, D., Abdel-Hamid, I., Atanasov, P. and Wilkins, E. (1999) Biosensors for Detection of Pathogenic Bacteria. Biosensors and Bioelectronics, 14, 599-624. http://dx.doi.org/10.1016/S0956-5663(99)00039-1 
[5] https://microbiologybytes.wordpress.com

[6] Rossi, T.M. and Warner, I.M. (1985) Pattern Recognition of Two-Dimensional Fluorescence Data Using CrossCorrelation Analysis. Applied Spectroscopy, 39, 949-959. http://dx.doi.org/10.1366/0003702854249501

[7] Beverly, M.B., Basile, F., Voorhees, K.J. and Hadfield, T.L. (1996) A Rapid Approach for the Detection of Dipicolinic Acid in Bacterial Spores Using Pyrolysis/Mass Spectrometry. Rapid Communications in Mass Spectrometry, 10, 455458. http://dx.doi.org/10.1002/(SICI)1097-0231(19960315)10:4<455::AID-RCM500>3.0.CO;2-Y

[8] Fox, A., Black, G.E., Fox, K. and Rostovtseva, S. (1993) Determination of Carbohydrate Profiles of Bacillus anthracis and Bacillus cereus Including Identification of O-Methyl Methylpentoses by Using Gas Chromatography-Mass Spectrometry. Journal of Clinical Microbiology, 31, 887-894.

[9] Goodacre, R., Shann, B., Gilbert, R.J., Timmins, E.M., McGovern, A.C., Alsberg, B.K., Kell, D.B. and Logan, N.A. (2000) Detection of the Dipicolinic Acid Biomarker in Bacillus Spores Using Curie-Point Pyrolysis Mass Spectrometry and Fourier Transform Infrared Spectroscopy. Analytical Chemistry, 72, 119-127. http://dx.doi.org/10.1021/ac990661i

[10] Quinlan, J.J. and Foegeding, P.M. (1997) Monoclonal Antibodies for Use in Detection of Bacillus and Clostridium Spores. Applied and Environmental Microbiology, 63, 482-487.

[11] Zhou, B., Wirsching, P. and Janda, K.D. (2002) Human Antibodies against Spores of the Genus Bacillus: A Model Study for Detection of and Protection against Anthrax and the Bioterrorist Threat. Proceedings of the National Academy of Sciences of the United States of America, 99, 5241-5246. http://dx.doi.org/10.1073/pnas.082121599

[12] Fergenson, D.P., Pitesky, M.E., Tobias, H.J., Steele, P.T., Czerwieniec, G.A., Russell, S.C., Lebrilla, C.B., Horn, J.M., Coffee, K.R., Srivastava, A., Pillai, S.P., Shih, M.T.P., Hall, H.L., Ramponi, A.J., Chang, J.T., Langlois, R.G., Estacio, P.L., Hadley, R.T., Frank, M. and Gard, E.E. (2004) Reagentless Detection and Classification of Individual Bioaerosol Particles in Seconds. Analytical Chemistry, 76, 373-378. http://dx.doi.org/10.1021/ac034467e

[13] Huang, J., Li, Y., Slavik, M.F., Tao, Y. and Huff, G.R. (1999) Identification and Enumeration of Salmonella on Sample Slides of Poultry Carcass Wash-Water Using Image Analysis with Fluorescent Microscopy. Transactions of the ASAE, 42, 267-273. http://dx.doi.org/10.13031/2013.13204

[14] Prosser, J.I., Killham, K., Glover, L.A. and Rattray, E.A. (1996) Luminescence-Based Systems for Detection of Bacteria in the Environment. Critical Reviews in Biotechnology, 16, 157-183. http://dx.doi.org/10.3109/07388559609147420

[15] Dickinson, B. (2002) Introduction to Flow Cytometry: A Learning Guide. Becton, Dickinson and Company, Franklin Lakes.

[16] Boye, E. and Loebner-Olesen, A. (1991) Bacterial Growth Control Studied by Flow Cytometry. Research in Microbiology, 142, 131-135. http://dx.doi.org/10.1016/0923-2508(91)90020-B

[17] Wu, L., Luan, T., Yang, X., Wang, S., Zheng, Y., Huang, T., Zhu, S. and Yan, X. (2014) Trace Detection of Specific Viable Bacteria Using Tetracysteine-Tagged Bacteriophages. Analytical Chemistry, 86, 907-912. http://dx.doi.org/10.1021/ac403572z

[18] Thevenot, D.R., Toth, K., Durst, R.A. and Wilson, G.S. (1999) Electrochemical Biosensors: Recommended Definitions and Classification. Pure and Applied Chemistry, 71, 2333-2348. http://dx.doi.org/10.1351/pac199971122333

[19] Turner, A.P.F., Wilson, G. and Kaube, I., Eds. (1987) Biosensors: Fundamentals and Applications. Oxford University Press, Oxford.

[20] Bănică, F.G. (2012) Chemical Sensors and Biosensors: Fundamentals and Applications. John Wiley \& Sons, Chichester. http://dx.doi.org/10.1002/9781118354162

[21] Cavalcanti, A., Shirinzadeh, B., Freitas Jr., R.A. and Hogg, T. (2008) Nanorobot Architecture for Medical Target Identification. Nanotechnology IOP, 19, Article ID: 015103. http://dx.doi.org/10.1088/0957-4484/19/01/015103

[22] Cavalcanti, A., Shirinzadeh, B., Zhang, M.J. and Kretly, L.C. (2008) Nanorobot Hardware Architecture for Medical Defense. Sensors, 8, 2932-2958. http://dx.doi.org/10.3390/s8052932

[23] Sethi, R.S. (1994) Transducer Aspects of Biosensors. Biosensors \& Bioelectronics, 9, 243-263. http://dx.doi.org/10.1016/0956-5663(94)80127-4

[24] Barak, O., Treat James, R. and James William, D. (2005) Antimicrobial Peptides: Effectors of Innate Immunity in the Skin. Advances in Dermatology, 21, 357-374. http://dx.doi.org/10.1016/j.yadr.2005.07.001

[25] Williams, D.D., Benedek, O. and Turnbough Jr., C.L. (2003) Species-Specific Peptide Ligands for the Detection of Bacillus anthracis Spores. Applied and Environmental Microbiology, 69, 6288-6293. http://dx.doi.org/10.1128/AEM.69.10.6288-6293.2003

[26] Lee, T.C., Yusoff, K., Nathan, S. and Tan, W.S. (2006) Detection of Virulent Newcastle Disease Virus Using a Phagecapturing Dot Blot Assay. Journal of Virological Methods, 136, 224-229. http://dx.doi.org/10.1016/j.jviromet.2006.05.017 
[27] Shabani, A., Mak, A.W.H., Gerges, I., Polychronakos, C. and Lawrence, M.F. (2006) DNA Immobilization onto Electrochemically Functionalized Si(100) Surfaces. Talanta, 70, 615-623. http://dx.doi.org/10.1016/j.talanta.2006.01.033

[28] Lenigk, R., Carles, M., Ip, N.Y. and Sucher, N.J. (2001) Surface Characterization of a Silicon-Chip-Based DNA Microarray. Langmuir, 17, 2497-2501. http://dx.doi.org/10.1021/la001355z

[29] Lee, J.F., Stovall, G.M. and Ellington, A.D. (2006) Aptamer Therapeutics Advance. Current Opinion in Chemical Biology, 10, 282-289. http://dx.doi.org/10.1016/j.cbpa.2006.03.015

[30] Awais, R., Fukudomi, H., Miyanaga, K., Unno, H. and Tanji, Y. (2006) A Recombinant Bacteriophage-Based Assay for the Discriminative Detection of Culturable and Viable but Nonculturable Escherichia coli O157:H7. Biotechnology Progress, 22, 853-859. http://dx.doi.org/10.1021/bp060020q

[31] Olsen, E.V., Sorokulova, I.B., Petrenko, V.A., Chen, I.H., Barbaree, J.M. and Vodyanoy, V.J. (2006) Affinity-Selected Filamentous Bacteriophage as a Probe for Acoustic Wave Biodetectors of Salmonella typhimurium. Biosensors and Bioelectronics, 21, 1434-1442. http://dx.doi.org/10.1016/j.bios.2005.06.004

[32] Shabani, A., Zourob, M., Allain, B., Marquette, C.A., Lawrence, M.F. and Mandeville, R. (2008) BacteriophageModified Microarrays for the Direct Impedimetric Detection of Bacteria. Analytical Chemistry, 80, 9475-9482. http://dx.doi.org/10.1021/ac801607w

[33] Kutter, E. and Sulakvelidze, A. (2004) Bacteriophages: Biology and Applications. CRC Press, Washington DC. http://dx.doi.org/10.1201/9780203491751

[34] Birge, E.A. (2006) Bacterial and Bacteriophage Genetics. Fifth Edition, Springer Science, New York.

[35] Ivnitski, D., Abdel-Hamid, I., Atanasov, P., Wilkins, E. and Stricker, S. (2000) Application of Electrochemical Biosensors for Detection of Food Pathogenic Bacteria. Electroanalysis, 12, 317-325. http://dx.doi.org/10.1002/(SICI)1521-4109(20000301)12:5<317::AID-ELAN317>3.0.CO;2-A

[36] Swenson, F.J. (1993) Development and Evaluation of Optical Sensors for the Detection of Bacteria. Sensors and Actuators B: Chemical, 11, 315-321. http://dx.doi.org/10.1016/0925-4005(93)85270-K

[37] Schneider, B.H., Edwards, J.G. and Hartman, N.F. (1997) Hartman Interferometer: Versatile Integrated Optic Sensor for Label-Free, Real-Time Quantification of Nucleic Acids, Proteins, and Pathogens. Clinical Chemistry, 43, 17571763.

[38] Raether, H. (1988) Surface Plasmons on Smooth and Rough Surfaces and on Gratings. Springer Verlag, Berlin.

[39] Taylor, A.D., Yu, Q., Chen, S., Homola, J. and Jiang, S. (2005) Comparison of E. coli O157:H7 Preparation Methods Used for Detection with Surface Plasmon Resonance Sensor. Sensors and Actuators B: Chemical, 107, 202-208. http://dx.doi.org/10.1016/j.snb.2004.11.097

[40] Fratamico, P.M., Strobaugh, T.P., Medina, M.B. and Gehring, A.G. (1998) Detection of Escherichia coli O157:H7 Using a Surface Plasmon Resonance Biosensor. Biotechnology Techniques, 12, 571-576. http://dx.doi.org/10.1023/A:1008872002336

[41] Tawil, N., Sacher, E., Mandeville, R. and Meunier, M. (2012) Surface Plasmon Resonance Detection of E. coli and Methicillin-Resistant S. aureus Using Bacteriophages. Biosensors and Bioelectronics, 37, 24-29. http://dx.doi.org/10.1016/j.bios.2012.04.048

[42] Tawil, N., Mouawad, F., Levesque, S., Sacher, E., Mandeville, R. and Meunier, M. (2013) The Differential Detection of Methicillin-Resistant, Methicillin-Susceptible and Borderline Oxacillin-Resistant Staphylococcus aureus by Surface Plasmon Resonance. Biosensors and Bioelectronics, 49, 334-340. http://dx.doi.org/10.1016/j.bios.2013.05.031

[43] Tawil, N., Sacher, E., Mandeville, R. and Meunier, M. (2013) Strategies for the Immobilization of Bacteriophages on Gold Surfaces Monitored by Surface Plasmon Resonance and Surface Morphology. The Journal of Physical Chemistry C, 117, 6686-6691. http://dx.doi.org/10.1021/jp400565m

[44] Taitt, C.R., Anderson, G.P. and Ligler, F.S. (2005) Evanescent Wave Fluorescence Biosensors. Biosensors and Bioelectronics, 20, 2470-2487. http://dx.doi.org/10.1016/j.bios.2004.10.026

[45] Ko, S. and Grant, S.A. (2006) A Novel FRET-Based Optical Fiber Biosensor for Rapid Detection of Salmonella typhimurium. Biosensors and Bioelectronics, 21, 1283-1290. http://dx.doi.org/10.1016/j.bios.2005.05.017

[46] Geng, T., Morgan, M.T. and Bhunia, A.K. (2004) Detection of Low Levels of Listeria monocytogenes Cells by Using a Fiber-Optic Immunosensor. Applied and Environmental Microbiology, 70, 6138-6146. http://dx.doi.org/10.1128/AEM.70.10.6138-6146.2004

[47] Liu, Y., Ye, J. and Li, Y. (2003) Rapid Detection of Escherichia coli O157:H7 Inoculated in Ground Beef, Chicken Carcass, and Lettuce Samples with an Immunomagnetic Chemiluminescence Fiber-Optic Biosensor. Journal of Food Protection, 66, 512-517.

[48] Marco, M.-P. and Barcelo, D. (1996) Environmental Applications of Analytical Biosensors. Measurement Science \& Technology, 7, 1547-1562. http://dx.doi.org/10.1088/0957-0233/7/11/002 
[49] Suleiman, A.A. and Guilbault, G.G. (1994) Recent Developments in Piezoelectric Immunosensors: A Review. Analyst, 119, 2279-2282. http://dx.doi.org/10.1039/an9941902279

[50] Si, S.-H., Li, X., Fung, Y.-S. and Zhu, D.-R. (2001) Rapid Detection of Salmonella enteritidis by Piezoelectric Immunosensor. Microchemical Journal, 68, 21-27. http://dx.doi.org/10.1016/S0026-265X(00)00167-3

[51] Pathirana, S.T., Barbaree, J., Chin, B.A., Hartell, M.G., Neely, W.C. and Vodyanoy, V. (2000) Rapid and Sensitive Biosensor for Salmonella. Biosensors and Bioelectronics, 15, 135-141. http://dx.doi.org/10.1016/S0956-5663(00)00067-1

[52] Koenig, B. and Graetzel, M. (1993) Detection of Viruses and Bacteria with Piezoelectric Immunosensors. Analytical Letters, 26, 1567-1585. http://dx.doi.org/10.1080/00032719308021481

[53] Plomer, M., Guilbault, G.G. and Hock, B. (1992) Development of a Piezoelectric Immunosensor for the Detection of Enterobacteria. Enzyme and Microbial Technology, 14, 230-235. http://dx.doi.org/10.1016/0141-0229(92)90071-U

[54] Prusak-Sochaczewski, E., Luong, J.H. and Guilbault, G.G. (1990) Development of a Piezoelectric Immunosensor for the Detection of Salmonella typhimurium. Enzyme and Microbial Technology, 12, 173-177. http://dx.doi.org/10.1016/0141-0229(90)90034-N

[55] Ben-Dov, I., Willner, I. and Zisman, E. (1997) Piezoelectric Immunosensors for Urine Specimens of Chlamydia trachomatis Employing Quartz Crystal Microbalance Microgravimetric Analyses. Analytical Chemistry, 69, 3506-3512. http://dx.doi.org/10.1021/ac970216s

[56] Neufeld, T., Schwartz-Mittelmann, A., Biran, D., Ron, E.Z. and Rishpon, J. (2003) Combined Phage Typing and Amperometric Detection of Released Enzymatic Activity for the Specific Identification and Quantification of Bacteria. Analytical Chemistry, 75, 580-585. http://dx.doi.org/10.1021/ac026083e

[57] Brooks, J.L., Mirhabibollahi, B. and Kroll, R.G. (1992) Experimental Enzyme-Linked Amperometric Immunosensors for the Detection of Salmonellas in Foods. Journal of Applied Bacteriology, 73, 189-196. http://dx.doi.org/10.1111/j.1365-2672.1992.tb02977.x

[58] Gehring, A.G., Crawford, C.G., Mazenko, R.S., Van Houten, L.J. and Brewster, J.D. (1996) Enzyme-Linked Immunomagnetic Electrochemical Detection of Salmonella typhimurium. Journal of Immunological Methods, 195, 15-25. http://dx.doi.org/10.1016/0022-1759(96)00076-2

[59] Gehring, A.G., Patterson, D.L. and Tu, S.I. (1998) Use of a Light-Addressable Potentiometric Sensor for the Detection of Escherichia coli O157:H7. Analytical Biochemistry, 258, 293-298. http://dx.doi.org/10.1006/abio.1998.2597

[60] Ercole, C., Del Gallo, M., Pantalone, M., Santucci, S., Mosiello, L., Laconi, C. and Lepidi, A. (2002) A Biosensor for Escherichia coli Based on a Potentiometric Alternating Biosensing (PAB) Transducer. Sensors and Actuators B: Chemical, 83, 48-52. http://dx.doi.org/10.1016/S0925-4005(01)01027-9

[61] Yang, L. (2008) Electrical Impedance Spectroscopy for Detection of Bacterial Cells in Suspensions Using Interdigitated Microelectrodes. Talanta, 74, 1621-1629. http://dx.doi.org/10.1016/j.talanta.2007.10.018

[62] Ghafar-Zadeh, E., Sawan, M. and Chodavarapu, V.P. (2010) Bacteria Growth Monitoring through a Differential CMOS Capacitive Sensor. IEEE Transactions on Biomedical Circuits and Systems, 4, 232-238. http://dx.doi.org/10.1109/TBCAS.2010.2048430

[63] Yao, L., Lamarche, P., Tawil, N., Khan, N., Aliakbar, A.M., Hassan, M.H., Chodavarapu, V.P. and Mandeville, R. (2011) CMOS Conductometric System for Growth Monitoring and Sensing of Bacteria. IEEE Transactions on Biomedical Circuits and Systems, 5, 223-230. http://dx.doi.org/10.1109/TBCAS.2010.2089794

[64] Limited, D.W.S. (1999) Introduction to Principles of Impedance. www.dwscientific.co.uk

[65] Owicki, J.C. and Parce, J.W. (1992) Biosensors Based on the Energy Metabolism of Living Cells: The Physical Chemistry and Cell Biology of Extracellular Acidification. Biosensors \& Bioelectronics, 7, 255-272. http://dx.doi.org/10.1016/0956-5663(92)87004-9

[66] Bard, A.J. and Faulkner, L.R. (2001) Electrochemical Methods: Fundamentals and Applications. Wiley, New York.

[67] Ehret, R., Baumann, W., Brischwein, M., Schwinde, A., Stegbauer, K. and Wolf, B. (1997) Monitoring of Cellular Behaviour by Impedance Measurements on Interdigitated Electrode Structures. Biosensors and Bioelectronics, 12, 2941. http://dx.doi.org/10.1016/0956-5663(96)89087-7

[68] Tahir, Z.M., Alocilja, E.C. and Grooms, D.L. (2005) Polyaniline Synthesis and Its Biosensor Application. Biosensors and Bioelectronics, 20, 1690-1695. http://dx.doi.org/10.1016/j.bios.2004.08.008

[69] Ruan, C., Yang, L. and Li, Y. (2002) Immunobiosensor Chips for Detection of Escherichia coli O157:H7 Using Electrochemical Impedance Spectroscopy. Analytical Chemistry, 74, 4814-4820. http://dx.doi.org/10.1021/ac025647b

[70] Yang, L., Li, Y. and Erf, G.F. (2004) Interdigitated Array Microelectrode-Based Electrochemical Impedance Immunosensor for Detection of Escherichia coli O157:H7. Analytical Chemistry, 76, 1107-1113. http://dx.doi.org/10.1021/ac0352575 
[71] Park, I.-S., Kim, W.-Y. and Kim, N. (2000) Operational Characteristics of an Antibody-Immobilized QCM System Detecting Salmonella spp. Biosensors and Bioelectronics, 15, 167-172. http://dx.doi.org/10.1016/S0956-5663(00)00053-1

[72] Koubova, V., Brynda, E., Karasova, L., Skvor, J., Homola, J., Dostalek, J., Tobiska, P. and Rosicky, J. (2001) Detection of Foodborne Pathogens Using Surface Plasmon Resonance Biosensors. Sensors and Actuators B: Chemical, 74, 100-105. http://dx.doi.org/10.1016/S0925-4005(00)00717-6

[73] Meeusen, C.A., Alocilja, E.C. and Osburn, W.N. (2005) Detection of E. coli O157:H7 Using a Miniaturized Surface Plasmon Resonance Biosensor. Transactions of the ASAE, 48, 2409-2416. http://dx.doi.org/10.13031/2013.20067

[74] Radke, S.M. and Alocilja, E.C. (2005) A High Density Microelectrode Array Biosensor for Detection of E. coli O157:H7. Biosensors and Bioelectronics, 20, 1662-1667. http://dx.doi.org/10.1016/j.bios.2004.07.021

[75] Boehm, D.A., Gottlieb, P.A. and Hua, S.Z. (2007) On-Chip Microfluidic Biosensor for Bacterial Detection and Identification. Sensors and Actuators B: Chemical, 126, 508-514. http://dx.doi.org/10.1016/j.snb.2007.03.043

[76] Shabani, A., Marquette, C.A., Mandeville, R. and Lawrence, M.F. (2013) Carbon Microarrays for the Direct Impedimetric Detection of Bacillus anthracis Using Gamma Phages as Probes. Analyst, 138, 1434-1440. http://dx.doi.org/10.1039/c3an36830k

[77] Shabani, A., Marquette, C.A., Mandeville, R. and Lawrence, M.F. (2013) Magnetically-Assisted Impedimetric Detection of Bacteria Using Phage-Modified Carbon Microarrays. Talanta, 116, 1047-1053. http://dx.doi.org/10.1016/j.talanta.2013.07.078 
Scientific Research Publishing (SCIRP) is one of the largest Open Access journal publishers. It is currently publishing more than 200 open access, online, peer-reviewed journals covering a wide range of academic disciplines. SCIRP serves the worldwide academic communities and contributes to the progress and application of science with its publication.

Other selected journals from SCIRP are listed as below. Submit your manuscript to us via either submit@scirp.org or Online Submission Portal.
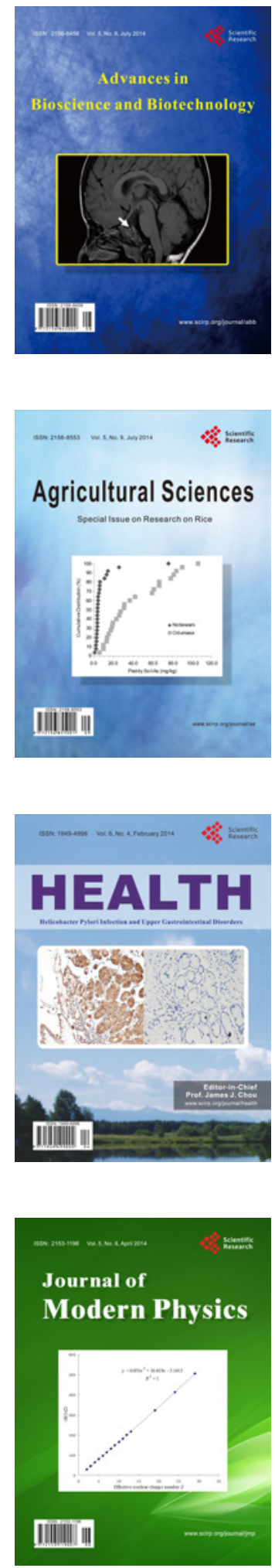
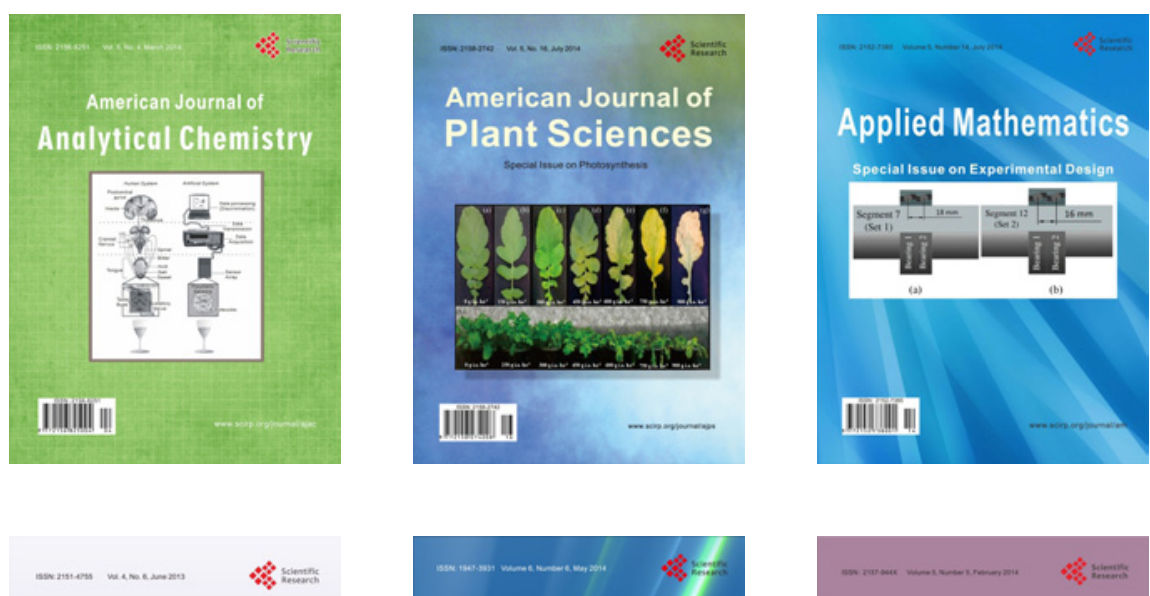

Creative Education
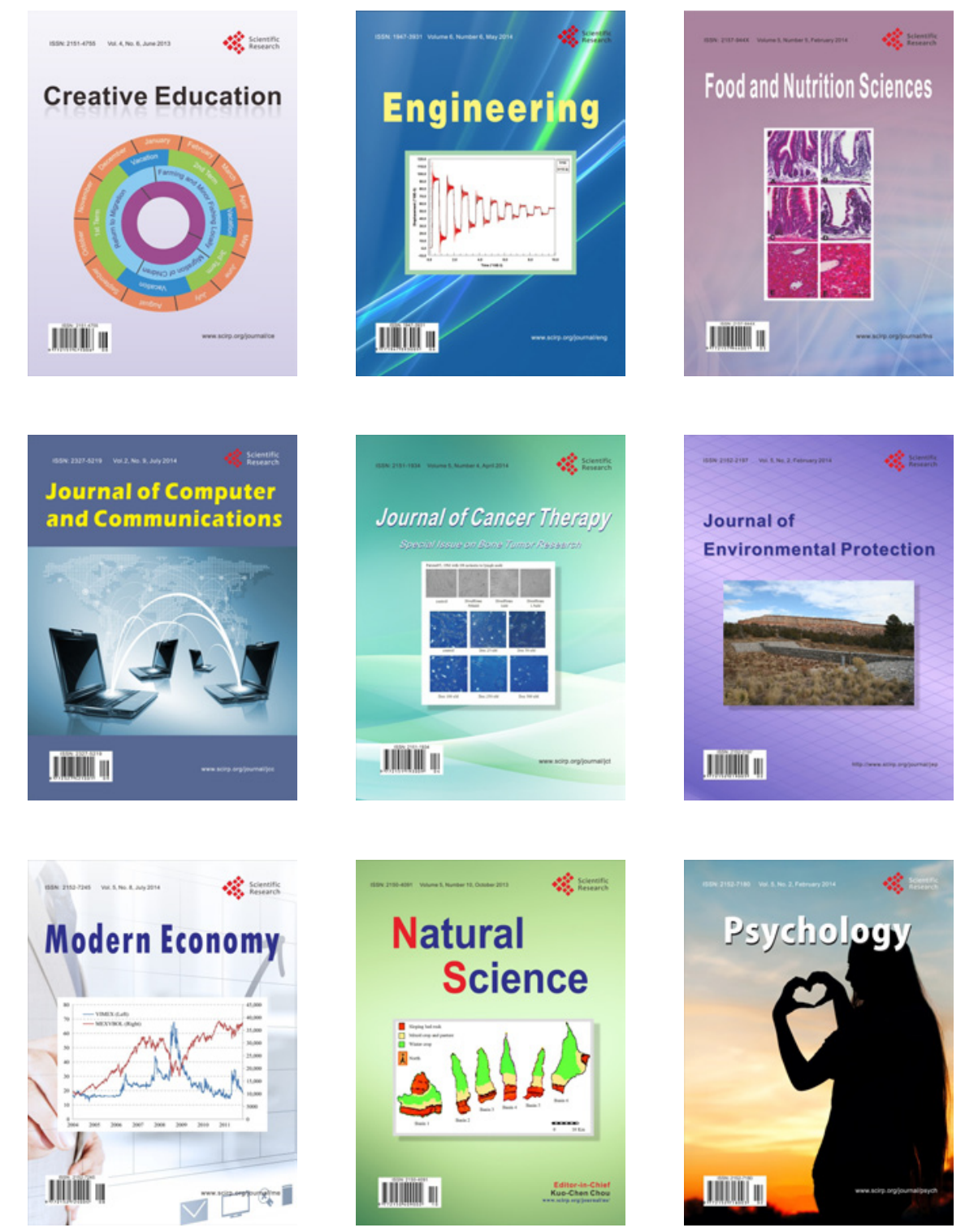